Interview m. Uffe Elbæk, tirsdag 2. september 2014, Christiansborg

\title{
Alternative visioner indenfor repræsentative rammer
}

\author{
Signe Blaabjerg Christoffersen \& Ditte Maria Brasso Sørensen \\ Ph.d. studerende, Institut for Statskundskab, Københavns Universitet
}

\section{Introduktion}

Dette temanummer adresserer spørgsmålet om politisk deltagelse fra forskellige perspektiver ansporet af de forandringer, der har været i det politiske landskab i de seneste årtier - både nationalt og internationalt - og som har fået både akademikere og politikere til at stille spørgsmålstegn ved demokratiets helbred (della Porta, 2013; Mair, 2006; Putnam, 2001; Keane, 2010).

Alternativet, med Uffe Elbæk i spidsen, har også meldt sig på banen i debatten om demokratiets helbred med input til, hvordan vi sikrer den deltagelse, der traditionelt set har givet demokratiet legitimitet (Lijphart, 1997). Alternativet har forsøgt at promovere sig som en generøs, handlingsorienteret, seriøs, og international organisation. Det er dog primært deres eksperimenter med nye deltagelsesformer, der har sat Alternativet på Danmarkskortet. De har, med egne ord, forsøgt at gentænke vores politiske kultur ved at appellere til vælgere, som ellers ikke har deltaget aktivt i det partipolitiske liv, hvilket er interessant fra en demokratisk og særligt en deltagelsesdemokratisk synsvinkel.

Alternativet taler på den måde til den overordnede spænding i temanummeret, nemlig spændingen mellem den parlamentariske og den ekstra-parlamentariske deltagelse. Alternativet forsøger at skabe et nybrud i dansk politisk kultur ved at sætte fokus på det demokratiske input gennem ekstra-parlamentariske deltagelsesformer, men bibeholder samtidig en parlamentarisk ambition. Alternativet forsøger at fokusere på den genuine og umedierede deltagelse - samme deltagelse, som Kutay (2015) mener, er truet af markedslogikker. Dette fokus får $\mathrm{Hu}$ sted (2015) til at forslå Alternativet som et eksempel på alternativ politisk deltagelse. Vi mener dog, at Alterna- tivets samtidige vægtning af repræsentation peger på, at Alternativet som organisation forsøger at styrke den repræsentative stukturs validitet ved at tilføje deliberation. På denne måde ligger Alternativets projekt i forlængelse af Böss (2015) forslag til, hvordan vi kan højne demokratisk legitimitet. Spændingen i Alternativets ambition, mellem den parlamentariske indflydelse og den ekstraparlamentariske deltagelse, sætter fokus på spørgsmålet om, i hvilken udstrækning vi skal forstå Alternativet som et alternativ? For at få et svar på dette spørgsmål og på spørgsmålet om, hvad vi skal lægge i visionen om en ny politisk kultur, satte vi Uffe Elbæk i stævne til en diskussion demokrati og nye former for deltagelse.

\section{Alternativets start}

Iden om Alternativet blev nedfældet i et konceptpapir (se http://alternativet.dk/alternativet-alternative/) i efteråret 2013 af Uffe Elbæk, tidligere Radikal kulturminister, grundlægger af og rektor for Kaospiloterne og direktør for World Outgames. Formålet var, ifølge Uffe Elbæk, ikke blot at skabe et nyt parti, men at skabe en bevægelse - en politisk bevægelse og en kulturel stemme, som partiet skriver på deres hjemmeside. Alternativet skulle være et parti med mod til at forestille sig en radikal anderledes fremtid. Et parti der kunne forene tanker om bæredygtighed og personlig frihed. Et parti med fokus på fællesskab og den enkeltes entreprenante skaberkraft. Et parti med fokus på kunsten og kulturens rolle i skabelsen af livsværdier og livsstrategier. Alternativet så det som sin første opgave at skabe en social åben, mangfoldig og netværksbaseret digital platform, hvor viden, kontakter og alternative politiske ideer kunne blive delt og videreudviklet på tværs af verdensdele, lande, byer og klassiske 
partiideologiske skel. Sideløbende med opbygningen af den digitale platform skulle en tilsvarende fysisk platform etableres.

Grundtanken for Alternativet var og er holistisk. Politik er ikke og bør ikke være begrænset til noget der foregår på Christiansborg. I stedet skal det politiske tænkes som en integreret del af det samfund, som det er en del af. Uffe Elbæk, forklarer:

„Med Alternativet ønsker vi at sætte fokus på, at der er brug for et nyt demokratisk sprog mellem det der foregår herinde på Christiansborg, og det der foregår udenfor Christiansborg. Der er politisk liv alle mulige steder, ikke kun på Christiansborg, og det er nødvendigt, at vi sikrer, at hverdagserfaringer og gode konkrete løsningsideer er med til at præge vores politiske debat."

Ideen om Alternativet som en bevagelse snarere end blot et parti dækker, ifølge Uffe Elbæk, over dette. Men den spænder også bredere. Den dækker også over ideen om, at man kan og bør kombinere de bedste elementer fra de offentlige og frivillige sektorer med de bedste elementer fra det private erhvervsliv. Som bevægelse bør man operere på markedsvilkår, men også samtidig sørge for at give noget tilbage til de lokalsamfund, som man er en del af - hvad enten det er Nørrebro eller Danmark. Idealet for Uffe Elbæk er, at partidelen fungerer som en integreret og autentisk del af et større hele - ikke som et selvkørende, professionelt projekt, der er dybt afhængigt af partistøtte. Ideen er ikke ukendt i Danmark, hvor Socialdemokratiet i mange år har opereret efter denne filosofi:

„Hvis man kigger på Socialdemokratiet, så havde de jo fagbevægelsen. De havde partiet som det offentlige element og så havde de kooperationen, som det private, med boligbyggerier og Arbejdernes Landsbank. Der lavede de jo virksomheder. De lavede også dagblade - Aktuelt og det Fri Aktuelt. Nu har de A4 og avisen.dk. Så egentlig har de jo også opereret indenfor alle tre af de gamle sektorer. På den måde er det ikke nyt, kan man sige. Men vi har så bare prøvet at sætte ord på det igen."

\section{Innovation i deltagelse - laboratorier \& lotterier}

Som et led i forsøget på at mobilisere befolkningen ønsker Alternativet ikke blot nye platforme for deltagelse, men også at skabe et nyt demokratisk sprog. Uffe Elbæk understreger, at der er et udtalt behov for større politisk engagement $\mathrm{i}$ befolkningen, hvis det repræsentative demokrati og dets institutioner, som vi kender det i dag, ikke skal blive tømt for legitimitet og bryde helt sammen:

„Det så vi i Rusland, i Sovjet: hvis et system mister legitimitet hos borgerne, så på et eller andet tidspunkt, så brager det sammen."

Med dette erklærede mål, og særligt med dets fokus på at skabe en ny platform for deltagelse indlejreti et bredere samfundsmæssigt og kulturelt projekt, forsøger Alternativet at adressere det, der i litteraturen er blevet betegnet som et stadigtvoksendedemokratisk problem, nemligden potentielle mangel på politisk legitimitet, der er opstået $i$ kølvandet på en dalende (traditionel) politisk deltagelse (Lijphart, 1997).

Alternativet har slået sig op på deres nytænkning indenfor borgerinddragelse, særligt de „politiske laboratorier", hvor borgere kan komme med forslag til partiets politik og debattere de stillede forslag. Ifølge Uffe Elbæk handler det om at anerkende, at borgere ikke bare formelt bør have en stemme i demokratiet, men faktisk har gode ideer at byde ind med - og at inddragelse derfor ikke bare handler om processuel legitimering, men også om indhold og substans.

„Dybest set tror jeg, at alle de der gode ideer allerede er derude i et eller andet format. Vi skal bare finde ud af at spotte dem."

Alternativet gennemførte i foråret 201420 politiske laboratorier (Elmhøj, 2014). Målet med laboratorierne var at bringe praktisk viden og nye ideer $i$ spil ved inddragelse af alle, som havde lyst til at bidrage. De afholdte laboratorier gav input til Alternativets partiprogram, der blev vedtaget i slutningen af maj 2014. Men selvom partiprogrammet er vedtaget er laboratorierne stadig relevante. Uffe Elbæk understreger, at det er vigtigt at blive ved med at debattere. De politiske laboratorier er med til at give stadig input til partiprogrammet.

„Vi havde et mini-laboratorium i torsdags [d. 31 august 2014 red.] ude på Nørrebroteater, hvor vi diskuterede køn, krop, og seksualitet. Der kunne igen alle folk bare tilmelde sig, vi anede ikke, hvem der gik ind af døren, og det er ideen, debatten skal være åben og ongoing."

Alternativet leger med tanken om en række andre nye initiativer til at øge deltagelsen. Fx har de, som Uffe Elbæk udtrykker det, „tyvstjålet“ ideen om Open-ministry 
fra Finland. Det Finske Open-Ministry initiativ er et nationalt borgerinitiativ i stil med det Europæiske Borgerinitiativ, der blev indført med Lissabontraktaken. Open Ministry giver borgere, der har samlet 50.000 underskrifter, mulighed for at sætte et emne eller et lovforslag på dagsordenen (Pekkanan, 2014). Tanken er, at man ved at „crowdsource“ lovgivning kan kanalisere de ideer, der diskuteres i samfundet, ind i Folketinget.

Uffe Elbæk bruger Dong-sagen som eksempel.

„Der var 200.000, der skrev under, men havde det overhovedet nogen indflydelse herinde? Nej, det havde det ikke. Hvis jeg havde været Corydon og vidste, at det her var en meget principiel beslutning, om hvorvidt vi skulle sælge ud af den offentlige infrastruktur i Danmark, så ville jeg nok have sørget for at involvere danskerne i overvejelserne og tænkt mere over, hvordan kan de komme ind i samtalen på det rigtige tidspunkt. Regeringen har i min optik lavet en kæmpe fejl. Og fejlen har rod i deres manglende lyst til at involvere danskerne i problemerne."

„Det er derfor, at der er brug for at eksperimentere med sådan noget i stil med Open Ministry-tænkning. Forestil jer, at når jeg skal ind og stemme i salen, eller hvem der nu skal ind og stemme i salen, ... at man har nogle sociale platforme kørende, der gør at folk derude kan kommunikere i real time, hvad de ønsker jeg skal stemme nede i salen."

Alternativet har indtil videre arbejdet med denne ide, som et eksempel på, hvordan vælgergrupper forud for en given afstemning kan involveres i komplekse politiske spørgsmål. På den måde mener Uffe Elbæk, at debatten i samfundet i højere grad vil kunne afspejle debatten på Christiansborg og omvendt - og dette kan, ifølge Uffe Elbæk, være en måde at genetablere den politiske tillid på.

Uffe Elbæk søger også inspiration i deltagelsesinitiativer fra Canada, MASS LDP og Peter Macleod, som er en af Alternativets internationale ambassadører. Inddragelsesværktøjer som trænede borgerråd udtrukket ved lodtrækning er bare ét eksempel på et initiativ der, ifølge Uffe Elbæk, kan inddrage befolkningen og uddanne denne til deltagelse.

„I forbindelse med budget-omlægninger indenfor sundhedssektoren har man spurgt folk, om de havde interesse i at være med til at vurdere, hvad et hospitals budgetpriorite- ringer skulle være. Blandt de interesserede blev der trukket et antal navne. De udtrukne kom så ind i et undervisningsforløb, der handlede om økonomiske prioriteringer og visioner i sundhedssektoren. At man havde udtrukket tilfældigt blandt de interesserede gjorde, at det var meget forskellige mennesker, der kom til at side ved bordet. Men i kraft af, at der var en mere styret, undervisnings- og vidensproces, så handlede det ikke bare om transparens, de fik faktisk også mulighed for at forstå, hvad det var for nogle dilemmaer, der lå på bordet."

Ønsket om at uddanne befolkningen til deltagelse er et centralt element i Uffe Elbæks vision for Alternativet, og måske netop derfor går han også ind for støtte til at fremme den offentlige debat generelt. Adspurgt om ønskværdigheden af økonomisk støtte direkte til civilsamfundet, som vi har set det i EU regi (se Kutay, 2015), siger Uffe Elbæk:

„Jeg har ikke noget imod, at man som stat eller offentlig institution går ind og understøtter demokratiet og den demokratiske procedure. Det synes jeg ikke er anderledes end, at vi vælger at bruge penge på Danmarks Radio eller bladhusene. Det synes jeg er vigtigt. Vi er et lille sprogområde, og hvis vi skal have et højt kvalitativt og forskelligartet mediebillede, så kan man ikke blot gøre det som en ren forretning."

\section{Alternativ deltagelse - et deliberativt ideal?}

Alternativets eksperimenter med deltagelsesformer leder tankerne i retning af deliberativ demokratiteori og de mange former for såkaldt demokratisk innovation, der er udsprunget heraf (se fx Saward, 2000). Idealet om deliberation, som det i sin tid blev formuleret af Jürgen Habermas (Habermas, 1996), men også som det er reformuleret af bl.a. Amy Gutman og Dennis Thompson (1996) hviler på gensidig respekt. Deliberativ demokratiteori tager udgangspunkt $i$, at demokratisk legitimitet kræver offentlige begrundelser, der skal være tilgængelige og forståelige for alle, der berøres af de vedtagne regler. Den deliberative model kommer derfor ikke med prædefinerede institutionelle forskrifter, men lægger i stedet vægt på debat og begrundelser - i tråd med Alternativets vision. 
Alternativets seks debatdogmer, der fremhæver samtalen og fremførelsen af saglige argumenter kan ses som et eksempel på det deliberative ideal i praksis:

1. Vi vil gøre opmærksom på både fordele og ulemper

2. Vi vil lytte mere, end vi vil tale, og vi vil møde vores politiske modstandere der, hvor de er

3. Vi vil fremhæve de værdier, som ligger bag vores argumenter

4. Vi vil indrømme, når vi ikke kan svare på et spørgsmål og indrømme, hvis vi har taget fejl

5. Vi vil være nysgerrige overfor alle dem, vi samtaler og debatterer med

6. Vi vil åbent og sagligt argumentere for, hvordan Alternativets politiske visioner kan nås

Qua deres centrale rolle i Alternativets praksis er dogmerne med til at sikre en rød tråd i Alternativets vision om en ny politisk kultur - en åben deltagelseskultur. De politiske laboratorier og dannelsen af et „bottom-up“ partiprogram er konkrete eksempler på, hvordan idealer om inklusion og deliberation har været med til at forme Alternativets politiske retning.

Visionen om deltagelse og åbenhed, som den ses hos Alternativet, står dog i potentiel modsætning til underliggende partipolitiske ideologier og værdier. Under interviewet forbliver det længe uklart for os, hvorvidt eller i hvilken udstrækning Alternativet skal forstås som en åben platform for de holdninger, der ligger i samfundet, eller Alternativet skal ses som en politisk organisation, der $ø$ nsker at promovere en bestemt ideologi. Hvis sandheden ligger et sted midt imellem, hvad er så givet, og hvad er til debat?

Mod. Mod til at se problemerne i øjnene, men også mod på den fremtid, der er vores.

Generøsitet. Alt, hvad der kan deles, skal deles med dem, der har lyst.

Gennemsigtighed. Alle skal have mulighed for at se os over skulderen- både på gode og dårlige dage.

Ydmyghed. Overfor opgaven, overfor dem, vi står på skuldrene af og overfor dem, der kommer efter os.

Humor. Uden humor ingen kreativitet. Uden kreativitet ingen gode idéer. Uden gode idéer ingen skaberkraft. Uden skaberkraft intet resultat.

Empati. At sætte sig i den andens sted og se verden derfra. Og derpå skabe løsninger, hvor alle vinder.
Uffe Elbæk fremhæver at de politiske laboratorier hviler på Alternativets værdigrundlag (se boksen nederst på denne side samt Alternativets manifest). Dette værdigrundlag er essentielt, både funktionelt og substantielt. Funktionelt fordi stærke værdier er nødvendige for aktivisme:

\section{„Vi har været meget bevidste om, hvordan vi har bygget der her op. Jeg skrev et grundkon- cept for Alternativet helt tilbage sidste år, i det lå der nogle meget bevidste greb, særligt det med at være så værdibaseret i den måde vi går til det på. Det afspejler, tror jeg, et behov."}

Netop denne værdibaserede tilgang har i følge Uffe Elbæk være et led i at tiltrække en række af de mennesker, der ikke har været medlemmer af et politisk parti før. Det har været en motivations-faktor. Uffe Elbæk anerkender, at det værdigrundlag Alternativt tilbyder kun er motiverende for nogle. Med andre ord, så er der en vis bias i rekrutteringen, og som Uffe Elbæk udtrykker det, så kan det nok ikke være anderledes:

„Når man ønsker på den måde at udvikle en ny politisk, men også økonomisk model og sætter bæredygtighed og lighed i centrum, så er det klart, at det tiltrækker de folk, der mener, at det er vigtigt, at vi har et lige samfund og ikke et ulige samfund, eller at der er andre succeskriterier i livet end at score kassen. Det har jeg det helt fint med, fordi vi vil ikke være et parti for alle."

Derfor er det også vigtigt at forstå, at værdierne ikke kun spiller en funktionel rolle, de er ikke kun et trækplaster for at få borgere til at møde op til laboratorierne, de har, sammen med visionen om et økonomisk og socialt, og miljømæssigt bæredygtigt samfund, også en substantiel rolle at spille i debatten. Alternativet ønsker at udforme en ny og bæredygtig vision for vores verden, som er løsrevet fra forestillingen om en neoliberal økonomi, og som i stedet hviler på en ide om et langt mere bæredygtigt samfund og et alternativt vækstbegreb. Værdigrundlaget og den bæredygtige vision har sat rammen for deltagelse:

\section{"Som udgangspunkt er disse to elementer} ikke til diskussion."

I tillæg til at sætte rammen, fungerer værdigrundlaget også som en kritisk standard, som Uffe Elbæk siger: 
Værdierne har særligt været brugt som gode guidelines i den interne debat. Men I skal huske på at værdierne derudover bliver suppleret med både debatdogmer og mediedeklaration. Tilsammen er det et udsædvanligt godt kvalitetsfilter og etisk benspænd, vi har. For vi bliver hele tiden nødt til at overveje, om vi lever op til vores egne værdier og åbenheds-kriterier. I forhold til udviklingen af partiprogrammet blev flere idéer valgt fra fordi det ikke hang sammen med partiets værdigrundlag."

Værdiernes meget konkrete rolle bliver måske endnu mere tydelig i det følgende:

„Vores værdier er kvalitetsfiltre vi kan måle konkrete forlag op i mod. De gør os i stand til at afgøre om et forslag er indenfor skiven eller uden for skiven. De 6 værdier giver os en standard - er det her et generøst initiativ? er det her et modigt initiativ? er det transparent? og passer det med den overordnede vision?"

Sådanne standarder eller rammer sikrer forventningsafstemning, og dette er centralt ifølge Uffe Elbæk. Det er vigtigt at være præcis på, hvad der er til diskussion, og hvad der ikke er til diskussion i borgerinvolveringsprocesser.

Værdigrundlaget afspejler samtidig, at der er klare grænser for hvad Alternativet vil repræsentere. Til spørgsmålet om, hvorvidt der er grænser for hvad Uffe Elbæk personligt vil stå som repræsentant for, svarer han:

„Ja for pokker da, ... vi går ud med vores bud på, hvordan vi løser de problemer, der er i samfundet, og det gør vi så vi på den måde, vi nu synes er den rigtige måde at gøre det på, og så må folk jo mene, at det er enten rigtigt eller forkert."

Hermed også sagt, at der nødvendigvis vil være meningsforskelle - også dybere ideologiske forskelle - i et samfund, som deliberation ikke nødvendigvis er løsningen på. I den forstand taler Uffe Elbæk ikke blot ind i en deliberativ forestillings ramme - han anerkender også potentiel konflikt, som den er blevet understreget af agonistiske demokrater, mest oplagt Chantal Mouffe (Mouffe, 2000). Lidt i modsætning til disse, mener Uffe Elbæk dog ikke, at det udelukker gensidig anerkendelse og respekt - en respekt, som bør udspringe af det, der trods alt er fælles for os som mennesker.
„Der kan være forskellige udlægninger af hvad det gode liv er, og dem skal staten ikke blande sig i. Men grundlæggende for alle er vores livskvalitet afhængig af om vi bliver respekteret. Det handler om at blive set og hørt. Indgår du i sociale relationer, der gør, du føler du hører til og, arbejder du med noget, der giver mening. Følelsen af respekt er grundlæggende fælles for alle mennesker - Kan jeg være her og vil de andre tillade, at jeg er her - og har de brug for mig. Hvis vi går ned og kigger på de helt psykologiske mekanismer, der skaber trivsel, så tror jeg godt, man kan sige, uagtet højre-venstre skaler, at det er fælles for os alle sammen som sociale væsener."

\section{Borgere versus eksperter}

Det er ikke kun værdier, der sætter grænser for, hvad deliberation indenfor det alternative fællesskab kan føre til. Alternativet har allieret sig med en række eksperter organiseret i de såkaldte Overgangsråd. Overgangsrådene kommer med anbefalinger og ideer til de emner, der er til debat, og „kvalitetssikrer“ på den måde Alternativets politik. Overgangsrådene har med andre ord haft mandat til at anbefale - men ikke forkaste.

Inddragelsen af eksperter i den demokratiske proces peger på, at spændingen mellem demokrati og teknokrati (se fx Christiano, 2012) også er en spænding, der er at spore i Alternativet. Spændingen afspejler et ønske om at balancere deltagelse og sandhedsværdi, eller med andre ord inklusion og behovet for holdbare og effektive løsninger. Som Uffe Elbæk udtrykker det:

\section{„Laboratoriets arbejde har sin egen proces. Overgangsrådene modtager referater, der beskriver hvad der er blevet diskuteret. De vurderer så, hvorvidt de synes, at de ideer eller anbefalinger, der blev produceret på laborato- riet levede op til deres forventninger og faglige standarder. Hvis der er vigtige emner, der ikke er blevet taget op på laboratorierne, så kan de også give anbefalinger til dem."}

Overgangsrådene er tænkt som en garant for, at beslutninger bliver truffet på det bedst mulige vidensgrundlag. Dette understreger på den ene side behovet for deliberation og troen på det gode argument. På den anden side risikerer man med dette fokus på ekspertviden, at kompromittere ideen om bred inklusion, der på mange måder danner grundlag for Alternativets projekt. Alternativets 
fokus på vidensbaseret politik-udvikling tillader potentielt, at "almindelige menneskers“ holdninger og synspunkter nedprioriteres eller måske ligefrem tilsidesættes. Uagtet dette, så står viden centralt.

„Jo mere folk ved, jo mere ender det også med at folk de finder hinanden. Min grundsæetning er, at konflikter opstår enten på grund af manglende information eller forkert information."

Dette er med til at understrege, hvordan det alternative projekt helt grundlæggende hviler på en ide om konsensus (om end muligheden for konflikt anerkendes), som den genfindes i liberale og deliberative demokrati teorier. Det er muligvis denne grundlæggende tro på konsensus, der gør, at Uffe Elbæk ikke ser nogen spænding mellem ekspertinddragelse og bred inklusion.

\section{Alternativets internationale potentiale}

Måske er det Uffe Elbæks tro på viden som en kilde til konfliktmediering, der er med til at styrke hans tro på Alternativet som et internationalt projekt. Uffe Elbæk siger:

„Interessen for Alternativet har faktisk været stor i udlandet. Vi er ikke alene, hvis du kigger på både, hvad der sker i Europa, men også videre ud, så er der mange andre bevægelser, der ligner Alternativet, der er begyndt at poppe op. Både som bevægelser, men også som partier. Og fællesnævneren, selvom man kunne have forskellige politiske kæpheste, er spørgsmålet om hvordan man udvikler den politiske kultur, og hvordan skaber vi et mere bæredygtigt samfund. Og det er uanset, om det er Nepal eller i Brighton, altså så er der folk lige nu, der er interesserede i den dagsorden."

Alternativet var fra starten tænkt som et internationalt parti - eller snarere en international bevægelse. Det betyder, at man kan være medlem af partiet uanset, om man bor i Danmark eller ej, men også, at Alternativet gerne vil dele sine erfaringer og viden med alle dem, der har lyst til at få adgang til det. Tanken er, at der på sigt kan oprettes reelle søsterpartier i andre lande. Faktisk er der allerede tilløb til dette i Sverige, Baltikum og Nepal. Derudover indgår Alternativet i flere internationale netværk. De har en tæt strategisk diskussion med det politiske miljø/tænketanken Compass i England, samt den dansk-svenske tænketank Metamoderna. ${ }^{1}$ Og de har haft flere møder med Feministisk Initiativ i Sverige. ${ }^{2}$ Begge dele er ek- sempler på ønsket og ambitionen om at dele erfaringer og udvikle idéer sammen. Endelig har Alternativet ambassadører i en række lande verden over.

Det er vigtigt her at understrege, at Alternativet ser det internationale samarbejde som supplement til det nationale demokrati. Alternatives projekt er ikke internationalt per se-om end det synes kompatibelt med kosmopolitiske grundholdninger. Demokratisk deltagelse tænkes stadig primært lokalt.

\section{Alternativet - en revitalisering af det repræsenta- tive demokrati}

Dette værdigrundlag og de deltagelses-politiske initiativer, som for manges vedkommende giver association til deliberative idealer, og som dermed skriver sig ind i en bredere international bevægelse, har dog deres begrænsninger. Det bliver ikke kun klart ovenfor i Uffe Elbæks erkendelse af, at fuldstændig konsensus ikke altid er mulig eller ønskværdig, det bliver særligt klart i de indikationer, der gives i ovenstående på, at interesserepræsentation stadig er et væsentligt aspekt af den demokratiske proces.

Selvom interesserepræsentation har været udskældt af flere radikale deliberative demokrater, bl.a. Iris Young (jf. Squires, 2000), så spiller dette element stadig en central rolle i det Alternative projekt. Med andre ord, deliberation, debat og innovation foregår og bør foregå, ifølge Alternativet, indenfor rammerne af det repræsentative demokrati og på den måde går Alternativets det repræsentative demokratis ærinde.

De deliberative idealer hviler på grundlæggende forestillinger om vores moralske kvalitet som mennesker, som Uffe Elbæk udtrykte det. Vi har som mennesker et behov for at blive set, hørt og respekteret. Heraf følger et behov for respektfuld interaktion og anerkendelse som et led i den demokratiske proces. Og selvom det repræsentative demokrati hviler på samme grundantagelser, så afspejler ideen om repræsentation også et praktisk forsøg på at oversætte denne moralske lighed til politisk lighed, når det kommer til at træffe faktiske beslutninger. Det repræsentative demokrati handler ikke blot om, hvordan vi delibererer og interagerer, men om hvordan vi træffer beslutninger på en måde, som respekterer vores politiske lighed - vores ret som borgere i et demokrati.

Denne nuanceforskel forklarer måske den velkendte spænding mellem deliberation og deltagelse på den ene side og repræsentation og beslutningsmyndighed på den anden side. Det repræsentative demokrati må træffe beslutninger og er på den måde blevet en garant ikke blot for moralsk lighed, men også for stabilitet, kontrol, lov og ret. Uffe Elbæk siger: 
„Hele ideen omkring det repræsentative demokrati er, at man jo selvfølgelig heller ikke bare skal løbe efter en hvilken som helst folkestemning. Problemet er så at finde ud af, hvornår man skal lytte til folkestemningen og hvornår man ikke skal - det er udfordringen. For at tage DONG som eksempel, så er spørgsmålet, hvornår man skal lytte til 200.000 mennesker, og hvornår man ikke skal lytte til 200.000 mennesker? Hvornår er det, at man bør være dybt medinvolverende, og hvornår bør man ikke."

Alt kan i princippet debatteres, men det er vigtigt at være meget præcis i forhold til, hvornår en given beslutning eller problematik er til debat indenfor rammerne af det repræsentative demokrati og behovet for beslutningstagning taget $\mathrm{i}$ betragtning:

„Man skal være meget præcis på, hvordan beslutningsprocessen er, og hvornår i den beslutningsproces man kan lave offentlig debat og gøre sin stemme gældende. Der er mange gange, hvor befolkningen kommer for sent ind i debatten. Det er et problem at det er uklart, hvornår i processen folk skal gøre deres stemme gældende."

Uffe Elbæk tilføjer:

„Dermed ikke sagt, at alle skal være med til at beslutte. Der er forskel på, om man diskuterer det i en bred offentlighed, eller om man siger, at nu skal alle have reel medbestemmelse. Schweiz, for eksempel, har valgt en anden model, hvor meget er til folkeafstemning. Vi har i Danmark valgt anderledes, vi har valgt det repræsentative demokrati, og dem der bliver valgt ind her i Folketinget, dem giver vi autoritet til at stemme nede i salen."

Det repræsentative demokrati er i følge Uffe Elbæk et vigtigt værn mod populisme. For mange folkeafstemninger vil ifølge Uffe Elbæk betyde en indbygget risiko for irrationelle beslutninger og populisme.

„Man skal passe på, at politikken ikke bliver et udtryk for, hvad der lige optager folk lige nu, og det er meget emotionelt."

Selvom humor, empati, og mod fremhæves i Alternativets værdigrundlag og udgør grundlaget for den demokrati- ske debat, så skal selve de politiske beslutninger være styret af rationalitet og fornuft. Politiske beslutninger skal helst være videnstunge, som vi så det i forbindelse med præsentationen af Overgangsrådene. Igen ser vi altså en spænding mellem Alternativets idealer om bred inklusion og deltagelse og en anerkendelse af behovet for repræsentation og arbejdsdeling. Sandelig, det er sidstnævnte, der ansporer idealet om videnstunge og velinformerede politiske beslutninger.

En spænding og en tvetydighed optræder sidst, men ikke mindst i Uffe Elbæks forhold til flydende demokrati. Selvom han er imod mange folkeafstemninger, så siger han:

„Jeg tror på, at flydende demokrati, hvor alt lægges ud til digital afstemning. Sådanne direkte feedback-systemer fungerer på nogle niveauer. Men der er også områder, hvor man bør afholde sig fra den form for deltagelse, fx etiske spørgsmål som spørgsmålet om aktiv dødshjælp. Jeg vil sige, at værdien og forsvarligheden af folkets deltagelse er meget kontekstafhængig."

Dette peger i retning af, at nogle spørgsmål ikke bør overlades til folket. Uffe Elbæk fremhæver her etiske spørgsmål, der ellers traditionelt er blevet betragtet som særligt politisk relevante. Robert Dahl, blandt andre, har argumenteret for at moralsk viden snarere end instrumentel, teknisk viden udgør baggrunden for inddragelse i den politiske proces - og vi er alle lige kompetente i moralske og/eller etiske spørgsmål (Dahl, 1985).

Alternativets grundholdning vedbliver da også ifølge Uffe Elbæk at være:

„Jo mere decentralisering, desto bedre. Jo mere involvering, desto bedre."

- alt sammen indenfor rammerne af det repræsentative demokrati, og ifølge Uffe Elbæk er der ikke nogen indbygget modsætning i dette.

Spændingen mellem den lokale deltagelse udenfor de etablerede rammer og den samtidige forståelse for de repræsentative strukturers validitet kan være med til at udfordre tesen om, hvorvidt vi skal forstå Alternativet som en organisering af alternative former for politisk deltagelse. Husted (2015) foreslår i sit bidrag til dette temanummer, at vi forstår Alternativet som en organisering af alternativ deltagelse med stabile lederskabspositioner og bygget på en differentiel logik. Spørgsmålet, der bør stilles, er, hvorvidt en så klar betoning af den repræsentative strukturs gyldighed, som her fremsættes af Uffe Elbæk, 
ikke underminerer ideen om Alternativet som en form for alternativ politisk deltagelse. Måske skal Alternativet i højere grad skal ses som et forsøg på at styrke det repræsentative demokrati, gennem øget deliberation. På denne måde kommer Alternativet tættere på Böss' (2015) ide om, hvordan vi opnår øget demokratisk legitimitet.

\section{Konklusion - Alternativets fremtid}

Alternativet har forsøgt at involvere en række borgere, som ikke normalt tænker sig selv som en del af partipolitik. De har forsøgt at eksperimentere med politikudvikling og opstille retningslinjer for den gode debat. De har forsøgt at åbne den politiske proces og skabe en ny politisk kultur. Hermed taler de ind i en tilbagevendende debat om deliberation og demokrati indenfor statskundskaben. En debat som også tydeligt er reflekteret i dette temanummers bidrag. Men som de gør det, træder en række modsætningsforhold frem. For eksempel står behovet for beslutningstagning indenfor rammerne af det repræsentative demokrati potentielt i modsætning til åben deltagelse. Ligesom en videnstung politisk proces ikke altid synes let forenelig med ideen om at tage borgernes ideer seriøst. Alligevel er alle inviteret til at deltage i det Alternative projekt - alle dem, der kan tilslutte sig det Alternative værdigrundlag.

Som antydet ovenfor behøver disse elementer måske ikke stå i modsætning til hinanden. Måske handler det simpelthen om at tænke vores traditionelle beslutningsproces i mere dynamiske termer; om at åbne processen op og inkludere nye elementer, som Uffe Elbæk siger:

„Vi vil gerne invitere dem ind, der har lyst til at diskutere de spørgsmål, der er vigtige for os. Der er alle mulige andre spørgsmål derude, men vi synes, de her er vigtige. Med udgangspunkt i de fokusområder har vi så lavet en proces, der er åben i den forste del af del og så lukker sig til sidst. Der har jo været folk, der har deltaget, der ikke var medlemmer af Alternativet. Der har været folk, der har deltaget, der var medlemmer af andre partier, men det kunne man godt rumme, fordi det netop var meget tydeligt, hvad der var til diskussion, og hvad der ikke var til diskussion. Den politiske retning var ikke til diskussion, den skulle vi ikke diskutere. Til gengæld var der masser af ting vi kunne diskutere konkrete løsningsforslag på konkrete problemstillinger. Det man også skal forstå, det er, at det var vores første bud på, hvordan kunne man lave en ny måde at lave et partiprogram på, og guderne må vide, hvordan det bliver fremadrettet, fordi vi lærte rigtig meget af processen."

Det er endnu uvist om Alternativet får en mere permanent rolle at spille på den danske politiske scene. Alternativet har nu fået indsamlet nok vælgererklæringer til at blive opstillingsberettiget. På spørgsmålet om, hvad der sker med Alternativet, hvis det ikke bliver valgt ind, svarer Uffe Elbæk tilbage i september 2014:

„Altså hvis du havde spurgt mig for et halvt år siden, så ville jeg være meget usikker på det.“

Hvad har ændret sig?

„Det der har ændret sig er jo, at vi har fundet ud af, hvor stort et ekko, der er derude, og hvor mange der gerne vil stille op og påtage sig helt formelle opgaver i organisationen, altså bestyrelsesarbejde både på landsplan og også lokalt. Personligt synes jeg, at det er glædeligt at se, hvor mange gode folk, der synes, at det her er vigtigt. Om det engagement kan holde gennem 4 års ørkenvandring indtil næste valg, det aner jeg ikke ... Men problemstillingen flytter sig i hvert fald ikke. Behovet er der. Spørgsmålet er om det er os, der kommer til at forløse det."

Hvis Alternativet bliver valgt ind, er spørgsmålet i hvilken udstrækning, Alternativt som parti kan repræsentere et reelt alternativ til det etablerede politiske system - og til det repræsentative demokrati. Sidstnævnte er givetvis ikke ønsket. Det alternative projekt skal måske snarere ses som et forsøg på at revitalisere den demokratiske proces, som vi kender den. Navnet forpligter dog partiet til at søge reelle politiske alternativer på et mere substantielt plan, mener Uffe Elbæk:

„Hvis jeg tager min organisations- og ledelses hat på synes jeg, at det er meget forpligtende navn, og det kan jeg rigtig godt lide, for det hele tiden tvinger os til at tænke over „kunne man gøre det på en anden måde“ ... Det der med hele tiden at være vågen; Er der andre løsninger end den der lige nu er på bordet. Det kan jeg godt lide. ... Der er så meget tradition. Derfor skal man være meget vågen og præcis, hvis man ønsker at vise, at det kan gøres ... anderledes." 


\section{Litteratur}

Alternativet (2015) Manifest, www.alternativet.dk/manifest, 25-032015

Böss M. (2015) Borgerinddragelse som opdragelse til repræsentativt demokrati Politik 18

Christiano T. (2012) Rational deliberation among experts and citizens. In: Parkinson J and Mansbridge J (eds) Deliberative Systems. Deliberative Democracy at the Large Scale. Cambridge: Cambridge University PRess, 27-51.

Dahl R. (1985) Controlling nuclear weapons: Democracy versus guardianship.

della Porta D. (2013) Can Democracy Be Saved, Oxford: Polity Press.

Elmhøj J. (2014) Alternativet har vokseværk. Information. http://www. information.dk/517033: Information.

Gutmann A and Thompson D. (1996) Democracy and disagreement. Why moral conflict cannot be avoided in politics, and what should be done about it., Cambridge, Massachusetts: The Belknap Press of harvard University Press.

Habermas J. (1996) Between Facts ad Norms: Contributions to a Discourse Theory of Law and Democracy, Cambridge: MIT Press.

Husted E. (2015) Organiseringen af Alternativ Politisk Deltagelse: Udkast til en Typologi. Politik 18.

Keane J. (2010) The life and death of democracy, London: Pocket Books. Kutay A. (2015) After Governance: A Normative Reflection on Civil Society Participation in Policy Processes. Politik 18.

Lijphart A. (1997) Unequal Particpation: Democracy's Unresolved Dilemma. Presidential Address, American Political Science Association, 1996. American Political Science Review 91: 1-14.
Mair P. (2006) Ruling the void: The hollowing of western democracy. New Left Review 42: 25-51.

Mouffe C. (2000) The democratic paradox: Verso.

Pekkanan J. (2014) Interview.

Putnam RD. (2001) Bowling alone, the collapse and revival of American community, New York: Simon and Schuster.

Saward M. (2000) Democratic Innovation: deliberation, representation, and association, London: Routledge.

Squires J. (2000) Group Representation, deliberation, and the displacement of dichotomies. In: Saward M (ed) Democratic Innovation deliberation, representation, and association. London: Routledge, 93-105.

\section{Noter}

1. Se http://ec.europa.eu/citizens-initiative/public/welcome?lg=da for mere information om det Europæiske borgerinitiativ.

2. Åbent Ministerium har været første behandlet i folketinget og er nu i udvalgsbehandling:

http://www.ft.dk/samling/20141/beslutningsforslag/b36/index. htm

3. For mere information om nedenstående og lignende initiativer se http://www.masslbp.com/journal.php.

4. Mere information om Compass og Metamoderna kan findes på henholdsvis http://www.compassonline.org.uk/ se og http://metamoderna.org/?lang=da

5. For mere information se; http://feministisktinitiativ.se/ 